April 1920

\title{
The Common-Law Right of Subrogation Under Workmen's Compensation Acts
}

Thomas P. Hardman

West Virginia University College of Law

Follow this and additional works at: https://researchrepository.wvu.edu/wvlr

Part of the Workers' Compensation Law Commons

\section{Recommended Citation}

Thomas P. Hardman, The Common-Law Right of Subrogation Under Workmen's Compensation Acts, 26 W. Va. L. Rev. (1920).

Available at: https://researchrepository.wvu.edu/wvlr/vol26/iss3/4

This Article is brought to you for free and open access by the WVU College of Law at The Research Repository @ WVU. It has been accepted for inclusion in West Virginia Law Review by an authorized editor of The Research Repository@WVU. For more information, please contact ian.harmon@mail.wvu.edu. 


\section{THE COMMON-LAW RIGHT OF' SUBBROGATION UNDER WORKMEN'S COMPENSATION ACTS}

\section{By Thomas P. Hardman*}

$\mathrm{T}^{\mathrm{T}}$ has been held or said in several cases, including a West 1 Virginia case, that when an employe has been injured by a third-party tort-feasor and has received compensation under a Workmen's Compensation Act, then, in the absence of special statatory provision to the contrary, not only may the employe recover full damages from the third party in a common-law action, but the administrator of the compensation fund has no right of subrogation for the compensation which he has paid, that is to say, is not substituted in the place of the injured employe so as to give him a right of reimbursement for the obligation which he paid but which in justice should be ultimately paid not by him but by the third-party tort-feasor. ${ }^{1}$ Many Workmen's Compensation Acts, however, expressly forbid a recovery of both "compensation" and common-law damages and provide that, if the injured worknan receives compensation under the Act, the administrator of the workmen's compensation fund is subrogated pro tanto to the rights of the injured workman against the third-party tort-feasor. Other Acts, including the West Tirginia Act, ${ }^{2}$ are silent upon the question. Quaere, then: Are the statutory provisions as to subrogation merely declaratory of a common-law principle? For, if there is no right of subrogation the cases allowing double recovery seen to violate the common-law rule that there may not be a double satisfaction for the same wrong. The question of subrogation being expressly covered by statute in many jurisdictions, it thus happens that there is comparatively little authority directly in point.

Where, as in West Virginia, the question is not covered by the

\footnotetext{
* Professor of Law, West Virginia University.

'See, c. g., Newark Paving Co. v. Klotz, 85 N. J. L. 432, 91 Atl. 91 (1914), lut see the subsequent amendment to the New Jersey Workmen's Compeusation Act, P. L. 1913, pp. 312, 313; Aetna Life Insurance Co. v. Otis Elevator Co., 204 S. W. 376, 2 W. C. L. J. 592 (Tex. Civ. App., 1918); City of Austin v. Johnson, 204 S. W. 1181, 2 W. C. L. J. 845 (Tex. Civ. App., 1918); Merrill $v$. Marietta Torpedo Co., 79 W. Va 669,92 s. E. 112 (1917) which relies upor. snd, for the point as to subrogation, must, in order to be understood, be read filth Mercer v. Ott, 78 W. Va. 629, 89 S. E. 952 (1916).

2See the various statutory provisions in 2 Honnold, WORKMEN's CoMpensatros, pp. 977-1706.
} 
statute it must, of course, be decided by the principles of the common law. Upon principle, then, doesn't the common law forbid such double satisfaction unless there is a coneomitant right of subrogation? With reference to this question a New York court, in a rather recent ease, made the following significant statement: ${ }^{3}$

"The reason for the statutory declaration [against recovering both compensation and common-law damages] . . . is founded upon the common-law rule that there should not be a double satisfaction for the same injury."

The same reason is also stated in Honnold on Workmen's Compensation. It would seem, therefore, that the cases allowing double recovery contravene well-settled prineiples of law unless the administrator of the workmen's compensation fund has a common-law right of subrogation, and the only question is whether he has such a right.

Fortunately the law of fire and marine insurance, $i$. e., indemnity insurance, furnishes a very close analogy. Thus, suppose that $A$ 's house worth $\$ 10,000$ is insured for $\$ 10,000$ by the $X$ Insurance Company. Through the negligence of $B$ the building is burned to the ground. A, after receiving $\$ 10,000$ from the Insurance Company, sues $B$ for damages. When $A$ is allowed to recover it is well settled that the Insurance Company is, without the aid of statute, subrogated to the right of the insured, that is to say, the loss is made to fall ultimately upon the party upon whom in equity it should fall, but the person insured, while receiving full indemnity, is not allowed to reap and retain a double satisfaction for the same wrong; and the Insurance Company having paid what in equity should be paid by the party at fault is subrogated to the insured's rights against that party. " Isn't the administrator of a workmen's compensation fund, then, who pays what the third-party tort-feasor should in equity pay, likewise subrogated pro tanto to the rights of the injured workman against the tort-feasor? It is true that the doctrine of subrogation has no application to an ordinary contract of life insurance, ${ }^{6}$ but that is, it seems, "because a contract of life insurance is not, like other

\footnotetext{
Maller v. New York Rys. Co., 157 N. X. Supp. 200, 201 (1916).

'HONNOLD, WOKKMEN'S COMPENSATION, \$ 46.

SSee Richards, InSURANCE I.AW, 3 ed., $\$ 52$ and authoritles therein cited.

Insurance Co. $v$. Brame, 95 U. S. 754, 24 L. Ed. 580 (1877); Aetna Life Ins. Co. v. Parker, 96 Tex. 287, 72 S. W. 168 (1903). See RIchard, op. cit., \$52.

'See Shaldon, Subrogation, 2 ed.. \$239.
} 
insurance, a contract of indemnity merely." And, paradoxical as it may seem, it is believed that the "life and accident" insurance under Workmen's Compensation Acts is in this aspect more closely analogous to fire and marine insurance, $i$. e., indemnity insurance, than to ordinary life insurance, for the object of Workmen's Compensation Acts is in reality to indemnify the employe for pecuniary loss sustained just as in case of fire and marine insurance where there is subrogation, and it is not largely to make a legally permissible wager on the duration of life or the happening of an accident as in the case of an ordinary life insurance policy where, because the contract is "not one of indemnity merely," there is no right of subrogation. Thus in compensation insurance the "average weekly earnings" of the injured person at the time of the injury are commonly made the basis upon which to compute benefits. "What the injured employe receives is "compensation" for loss sustained, that is to say, the employe is merely being "indemnified" just as in the cases of fire and marine insurance, which is not so in the case of ordinary life insurance. Of course the compensation granted under the Act may not be full indemnity for every form of injury. ${ }^{10}$ For example, compensation recoverable under the Act may be limited to a fixed sum which is in a particular case less than the estimated loss. But neither is the compensation paid under a fire or other indemnity insurance policy necessarily full indemnity, e. g., a house worth $\$ 10,000$ may be insured for $\$ 1,000$ only or against fire caused otherwise than by lightning, etc. In both compensation cases and fire insurance cases the indemnity is only to the extent provided for in the policy, the Workmen's Compensation Act being in practical effect the policy in compensation cases and providing in general only against loss in capacity to work, just as a fire insurance policy may provide only against certain kinds of loss.

It has been said, in support of the proposition that there should be no subrogation. in compensation cases, that the measure of damages is so different in the common-law action and in the suit for

BSee e. g. West Va. Workmen's Compensation Act, §31; Marhoffer v. Marhoffer, 8.20 N. Y. 543, 116 N. F. 379 (1917).

-But see Marhoffer v. Marhoffer, supra, n. 8.

${ }^{10}$ This is evidently what the court meent in Marhofier $v$. Marhoffer, supra, where 
compensation that the principles of subrogation are inapplicable.11 For example, damages for mere disfigurement or mere mental anguish, not resulting in loss of earning capacity, if recoverable at all as "compensation" under a Workmen's Compensation Act, would of course not be recoverable in full measure at least under the ordinary form of compensation act. But why this should render the doctrine of subrogation inapplicable is not apparent, for the measure of damages in an action on a fire insurance policy may be quite different from the measure of damages against the tort-feasor who caused the fire. Besides, in any case the injured workman, like the insured under a fire insurance policy, receives the full measure of damages recoverable in the common-law action, and the administrator of the compensation fund is subrogated only to the extent that he is to be repaid out of the common-law damages the amount of compensation which he has paid to the injured party. In other words, the injured employe will in all cases receive the full measure of damages for all injuries sutained, whether mere disfigurement, mental anguish or otherwise.

It may be said that, where the workman, by deduction from his pay or otherwise, pays a premium for this form of "life and accident" insurance, he, therefore, takes the chance of not being injured, and, therefore, should be entitled to the benefit of his bargain in addition to his common-law right against the thirdparty tort-feasor, for, even if he did not pay into the workmen's compensation fund, i. e., insure, he would have his action against the third party. But the prime purpose of the compensation insurance is to provide absolute assurance of recovery (even if limited recovery) in all cases coming within the Act, for it might be impossible to recover in some cases, e. g., against the third-party tort-feasor, and it is primarily for this absolute assurance that the employe pays his premium. Besides, the insured pays a similar sort of premium in fire and marine insurance cases where it is settled law that there is a right of subrogation.

The fire and marine insurance cases-the indemnity insurance cases-then, are, it would seem, substantially on all fours with the compensation cases; in fact, the workmen's compensation fund in West Virginia and in some states is an insurance fund and the workman is in an accurate sense insured against injuries. His right

it was said that "the theory of the New York law is not indemnity for loss of a member or physical impairment as such, but compensation for disability to work made on the basls of average peekly wages."

uNewark Paving Co. v. Klntz, supra, n. 1. 
to compensation in cases within the Act is absolute and irrespective of fault in others. The analogy, therefore, seems to be about as complete as analogies ever are, and if the fire or marine insurance company which pays for the loss is, without the aid of statate, subrogated pro tanto to the rights of the insured against the tort-feasor, by parity of reasoning the administrator of the workmen's insurance fund, who pays the insured workman what in equity should be paid by the tort-feasor, is likewise subrogated pro tanto to the rights of the injured workman against such wrong-doer; in other words, the provisions to that effect in many Workmen's Compensation Acts are only declaratory of a commonlaw principle, being founded upon the common-law rule originating in equity but now generally enforced also at law that when one has been compelled to pay an obligation which ought to have been paid by another the former is entitled to exercise all the remedies which the latter possessed against that other and to indemnity from the fund out of which should have been made the payment which he has made. ${ }^{12}$ T'he doctrine of subrogation is independent of statute and independent of any privity or contractual relations betwen the parties to be affected by it, ${ }^{13}$ and, as is well said by Justice Sheldon" "it is broad enough to include every instance in which one party pays a debt for which another is primarily answerable, and which, in equity and good conscience, should have been discharged by the Tatter."

The doctrine of subrogation is not formal or technical and it has been said judicially that he who in administering it would "stick in the letter" forgets the end of its creation and perverts the spirit that gave it birth. It is a creature of equity and essential justice is its object. ${ }^{x}$

The right of subrogation is based upon the doctrine of indemnity, and, being a creature of equity, created to do equity, its purpose is to throw the ultimate responsibility upon the one upon whom in equity it should fall, and to indemnify the innocent party who pays. The loss in workmen's compensation cases should fall ultimately upon the tort-feasor and as there is no equity in favor of the injured person to allow him to receive a double satisfaction for a single wrong--a thing forbidden by settled principles

12See SHELdow, op. cit., \$11.

${ }^{23 B a s s e t t}$ v. Strelght, 78 W. Va. 262, 88 S. E. 848 (1016).

"SHErdon, op. cit., 81 . Italies ours.

15Hawker v. Moore, 40 W. Va. 19, 20 S. F. 848 (1894). 
of law-and as such double recovery would unduly deplete the workmen's compensation fund at the expense of innocent employes and employers and to the unjust enrichment of the twice-paid employe, it is submitted that the administrator of the workmen's com. pensation fund, upon payment of compensation, is, without the need of a statutory provision, subrogated pro tanto to the rights of the injured employe against the third-party tort-feasor. This will indemnify the administrator of the fund for all compensation paid, and at the same time will fully indemnify the employe for all damage sustained, for, as we have seen, if the damages recoverable against the tort-feasor are greater than the compensation recoverable under the Act, the employe will receive ultimately the larger sum, for it is a settled principle of subrogation that in the absence of express stipulation the doctrine is nerer to be applied so as to prevent the injured party from being fully indemnified..$^{13}$ Thus everyone is fully paid, no one twice paid and the loss falls ultimately upon the only party at fault-the only equitable result.

iophoenix Insurance Co. v. First National Bank, 85 Va. 765, s 8. E. 719 (1889). See RICHards, INguraNce Law, \$52. 